\title{
Life experiences of elderly with cancer pain: the existential comprehensive approach*
}

\author{
Vivências de idosos com a dor oncológica: abordagem compreensiva existencial \\ Vivencias de ancianos con el dolor oncológico: abordaje comprensivo existencial
}

Kesley de Oliveira Reticena ${ }^{1}$, Margrid Beuter ${ }^{2}$, Catarina Aparecida Sales ${ }^{3}$

\begin{abstract}
* Extracted from the dissertation "Compreensão fenomenológica existencial da dor oncológica vivenciada por idosos: perspectivas para os cuidados de enfermagem," Post-graduate Nursing Program, Universidade Estadual de Maringá, 2014.

${ }^{1}$ Master, Post-graduate Nursing Program, Universidade Estadual de Maringá, Maringá PR, Brasil.

${ }^{2}$ Professor, Nursing Departament, Universidade Federal de Santa Maria, Santa Maria, RS, Brasil.

${ }^{3}$ Professor, Post-graduate Nursing Program, Universidade Estadual de Maringá, Maringá, PR, Brasil.
\end{abstract}

\section{ABSTRACT}

Objective: Understanding the experiences of elderly with cancer pain. Method: Qualitative research based on Heidegger's phenomenology. 12 elderly cancer patients from a city in northwest Paraná were interviewed from November 2013 to February 2014. Results: Analysis performed by vague, median and interpretive understanding which resulted in two ontological themes: Cancer pain: unveiling the imprisonment and impositions experienced by the elderly, and Unveiling the anguish of living with cancer pain; it revealed not only how the elderly experience pain in their daily lives, but also how hard it is to live with its particularities. Conclusion: Cancer pain has biopsychosocial repercussions for the elderly, generating changes in their existence in the world, requiring holistic and authentic care.

\section{DESCRIPTORS}

Aged; Neoplasms; Pain; Oncology Nursing. 


\section{INTRODUCTION}

Aging is a process characterized by several changes in the biological, psychological and social spheres of the human being. Such changes directly reflect in the way that the elderly will face, adapt and meet their new needs resulting from age ${ }^{(1)}$.

Population aging is a current worldwide phenomenon, and one of the greatest challenges of public health ${ }^{(2)}$. A change in the epidemiological profile of the population characterized by a high incidence of chronic conditions can be observed in this context which mainly affects the elderly ${ }^{(2-3)}$.

Among non-transmittable chronic diseases, one of the most feared is cancer. Its incidence increases considerably with aging due to the accumulation of risk factors acquired over the years ${ }^{(2)}$. When facing a diagnosis of such a disease, the patient experiences many transformations and changes in their daily life, resulting from the treatment and stigma. At this stage, the patient's focus is on the physical limitations imposed by the disease, associating it to pain, fear of being dependent on other people, and fear of death ${ }^{(4)}$, when the patient is an elderly person.

Pain is a common symptom in cancer patients and may be associated with the development of the disease, as well as other comorbidities due to diagnostic and therapeutic procedures $^{(3,5)}$. It may exceed the threshold of physical dimension and extend to others, such as psychological, financial, economic, emotional, social and spiritual dimensions, and therefore be characterized as total pain ${ }^{(6)}$. Consequently, pain is constituted as the most feared symptom among patients with cancer that seriously affects their daily life activities, bringing discomfort, diminishing motivation and life expectancy $y^{(7)}$.

When the disease and pain affect the elderly, it should be taken into account that the aging process gives rise to physiological changes in the human body, and when elderly are exposed to cancer treatments they can be more sensitive to some painkillers, with the possibility of expressing higher potential for adverse effects, toxicity and metabolism problems with the drug, requiring carefully calculated doses of opioids to obtain adequate analgesia ${ }^{(8)}$. Subsequently, there may be an intensification of pain, which affects facing treatment of the disease and quality of life of the elderly.

All people and health professionals close to an elderly cancer patient must engage with their pain and know how to contemplate it in all its aspects ${ }^{(7)}$. Therefore, it is essential to listen to the elderly patient in painful situations and seek alternatives to alleviate their suffering and providing means for the existence of the right to live in dignity ${ }^{(9)}$.

Given this information and experienced care to cancer patients in a municipal service home care, one of the authors was disturbed to realize that most cancer patients were elderly and they had, among other symptoms, pain which directly interfered in their quality of life. Thus the following research question was raised: What is the meaning of living with cancer pain in old age?

The importance of this study is justified, since it does not only seek to know the measured intensity of the pain caused by cancer and felt by human beings in old age, but aims to promote comprehensive care to these beings to embrace their subjectivities to live with cancer pain. This understanding can contribute to the holistic nursing practice, giving support to professionals working with geriatric oncology and pain. This study aims to understand the experience of cancer pain for the elderly.

\section{METHOD}

This is a qualitative research approach based on the assumptions of Heidegger's existential phenomenology that seeks to reveal the occurrence in its senses and meanings, allowing the achievement of its essence and aspects of existential dimension ${ }^{(10)}$. Therefore, the direct language from one's own mouth is used because the speech is steeped in human existence as production of society and acts as activity in the daily life of being ${ }^{(11)}$.

An examination of the subjects was through visits to 15 Basic Health Units in a municipality of the Northwest region of Paraná. Within them, the professionals of the Family Health Strategy indicated the elderly patients with cancer assigned to their areas of coverage. The subjects were selected based on inclusion criteria for the study: an age less than 60 years; be aware of their cancer diagnosis; have experienced pain of moderate to severe intensity (assessed by visual analog scale) after the discovery of diagnosis and preserved cognitive conditions (assessed using the Mini Mental State Examination). Death or city change during data collection and inability for verbal communication to answer the questions were adopted as exclusion criteria.

Subsequently, a visit to the specified elderly patient's home was done together with a Community Health Agent, observing the care of all the inclusion criteria of the study. If the case was positive, the patient was invited to participate, and if the patient agreed, other visits were scheduled according to their availability. 31 home visits to seniors with cancer were conducted during the period of November 2013 to February 2014. Of these, 12 met all inclusion criteria and became the research subjects. Each received two to three visits prior to the interview in their home, so there would be to opportunity to create bonds and empathy between the participant and the researcher. The interviews were guided by a semi-structured questionnaire with demographic data, disease information and the main question of: How is/was the pain that you are/were living with at this moment of your life?

Each interview was recorded with the aid of a digital recorder, lasting on average 40 minutes, and later transcribed in full by the researcher. Careful and exhaustive reading of each statement for analysis based on Heidegger's existential proposal followed. This determines two comprehensive methodical moments: first, it is the vague and general understanding which seeks to highlight the existential meanings, the most obvious signs in everyday life, showing how the human being is expressed through speech, silence and behavior; the second moment is the interpretive understanding, which seeks to discover the meaning of the subject itself, through the understanding of their meanings ${ }^{(10,12)}$. Firstly, the parts or units of meaning separated from each statement were shown as fundamental structures of existence, and that revealed the mean- 
ings of feeling cancer pain in old age. These units of sense/ feeling made up the thread of interpretive understanding, as they were analyzed and grouped from the phenomenological language selection of each subject.

Two ontological themes came from the testimonies which were interpreted in light of some Heideggerian ideas, the authors referring to the philosopher, as well as researchers who discuss the topic of this study.

To ensure the anonymity of respondents, they were named based on noticeable features evidenced during the meetings and after consulting the meaning of each word, the following nicknames were defined: Charisma, Determination, Strength, Hope, Love, Faith, Resignation, Courage, Charity, Melancholy, Sensitivity and Grace.

This study was approved by the Standing Committee on Ethics in Research Involving Human Beings of the State University of Maringa, under Opinion No. 256,521 / 2013. The ethical aspects regulated by Resolution No. 466/2012 of the National Health Council were complied with in full, and the Informed Consent forms were signed on two identical copies by all participants.

\section{RESULTS}

The 12 respondents had ages ranging from 65-77 years, with an average of 70 years. Of these, ten were women. Regarding marital status, nine were married, two divorced and one was widowed. For the years of education, three were illiterate; five had from one to four years of study and four had ten years of study or more. In terms of occupation, six were retired, five were housewives and one was a hairstylist. Nine seniors were Catholics and three Evangelicans.

The sites affected by cancer were varied among participants; reaching the spine, breasts, bowel, bladder, vaginal vault, lymph nodes, kidney and liver.

Next, the ontological issues that emerged from the analysis of the reports are presented.

\section{CANCER PAIN: UNVEILING THE IMPRISONMENT AND IMPOSITIONS EXPERIENCED BY THE ELDERLY}

On this theme, the elderly revealed their pain by entering into their life context; it makes them feel restrained to perform their daily life activities, depriving them of their social, professional and personal routines, making them feel trapped by cancer and pain.

$$
\begin{aligned}
& \text { Ifelt a lot of pain and I still do, it still hurts. Ifeel } \\
& \text { these sharp pains and it seems like there is a knife } \\
& \text { cutting in. It is strong and it disturbs me, because } \\
& \text { you cannot do any work, nor leave the house, I } \\
& \text { don't go out, I can't get out because of the trem- } \\
& \text { bling, I feel myself shaking and it hurts (Faith). } \\
& \text { It hurts me a lot because I became totally limited, } \\
& \text { it hurts to be still, the fact that I cannot do any- } \\
& \text { thing, just cannot do anything, and I feel very } \\
& \text { bad (Melancholy). } \\
& \text { Oh, dealing with the pain is difficult, isn't it? } \\
& \text { Pain gives us agony, wow! It makes us nervous }
\end{aligned}
$$

and then you need to take medicine, because otherwise you cannot handle it. It really disrupts our daily activities, you do not have the energy to do anything if you are in pain, you just want to lie down. But this is how is, life goes on, but it's tough, it's hard, but ... Taking medication every time I feel pain helps, then I'm able to do a little bit more, laying down for a while, walking a while, eating, when the pain subsides I eat a little, I'm able to sleep, to go out. In pain, you don't even leave the house (Determination).

It was hard to endure the pain day and night, it would start anytime, anytime at all... I did not have ... it was ... well, I did not have any expectation for life, because you say how long will this last? How can I live with it? Can I handle this? Pain is day and night, it has no time. There are times that it lets up, then you say, ah, will I improve? Suddenly it starts all over again, then you cannot go anywhere, you cannot even leave the house (Hope).

A closer look at their daily lives found that the pain also made them experience specific situations, which made them hostages of its facets, changing their basic needs such as food.

With the medication I was taking for pain, I could not eat, I did not eat, I did not want to eat, it bothered me down a lot. And I lost soo much weight, I used to weigh 70 kilos or so, today I weigh 60 kilos and a bit. I became thin, I was thin. To this day my diet is very little, I eat very little, the amount has decreased, and even today it is still not normal. I used to eat a lot, now I just eat a little (Hope).

I felt really awful and sick, I did not eat at all, all food for me stank, it was really an amazing thing, at 80 kilos I went down to 55, I do not know what happened, I did not eat. With the pain I could not even smell food, only liquids, (...) but even when I managed to eat a little, it took me a long time to eat a plate of rice and beans, a long time, they (my daughters) made soup, I had a little soup, but my stomach did not seem to accept it, I threw it all up (Strength).

The discomfort of pain during sleep, which affected their rest and comfort, was also referred to by the elderly.

The pain bothered me, I hardly slept, it interfered in everything. At the time I could not sleep because of the pain, I was really quiet, taking my pain medicine, Tramal, dipyrone, and I had another medicine also for pain, to be able to sleep (Love).

Sleeping bothered me because it hurt too much, I could not move my arm, I had to stay in only one position, in a position with my arm raised. It hurt a lot, especially when I had the catheter. Wow, that hurt too much, I could only sleep on my 
back, just my back, and then also to sleep I would put a pillow to raise my arm to support it, it was very painful, I suffered a lot (Melancholy).

Another burden of cancer pain was the difficulty of interacting with others, causing social and emotional relationships to fray, leaving the elderly increasingly isolated.

It's hard not sleeping well, not eating right, not directly relating with family, often, and with others as well, this is very hard (Charisma).

Look, it was too hard! Wow! I was so sad, my God! I could not do anything, it was just sitting, I could not stand up, sometimes visitors came and even when they were leaving I stayed sitting because I could not even get up (Strength).

In the days that I feel pain, it makes you just want to lie down, I just feel like keeping quiet. I do not like, well, I would not want anyone to talk to me (Sensitivity).

\section{UNVEILING THE ANGUISH OF LIVING WITH CANCER PAIN}

Even with the pain causing sadness and leading the elderly to question the meaning of their life, the will to cure their illness was so great that they tried to overcome it or adapt, not giving up the will to survive cancer:

\section{Ah, when it hurts too much, wow! It discourages us, really! There are times when I tell myself I'm alive, but... I look back and think about the things before. We have to raise our heads and go forward, right? (Determination).}

On the other hand there are times when the pain reaches the boundary between living and death. When the pain exceeded their tolerance threshold, it became unbearable to the point that through faith they would ask God to take their lives from them, or in a more complex prism, the desperation of being stuck living with cancer pain led them to think about committing extreme acts such as suicide.

I had a slight feeling that I had reached the end of the tunnel, I did not see another light, no. I was afraid and I see the situation getting worse every day, I lost weight, I felt a lot of ... Oh, you want me to tell you the truth? In fact, I even found myself so fragile, so bad, I asked God, I asked many times, I said: Look, Lord, if it be Thy will, I will not ask for death because it is sin, but if it is thy will, and I have to live like this, like this for a long time, if the Lord will take me I will be very pleased. I asked if God wanted it to be of His will and He wanted to take me for relief, I would prefer it. I think anyone would rather die than stay suffering as I was (Charisma).

It began little by little, and I spoke to her (my daughter) aww, it seems that the pain's coming again, then it came, it came little by little, just when you think no, it changed, it changed like a fire, and became very strong, even during the time I stayed lying or sitting, I got up, I squeezed her (my daughter), there wasn't any good place for me. I asked up to God, Lord if it was the time to take me, because I cannot stand it anymore (Strength).

Look, I thought of giving up treatment and even thought sometimes if I am to live with this pain all my life ... I won't be able to stand it! I'll have to ... I'll have to stop it. I even thought about suicide. People think about suicide, don't they? Because the pain is too much! It is not just a little! It's a lot of pain! I got to thinking about it, and my family disagreed. But I thought, and thought (Hope).

\section{DISCUSSION}

In his existence-in-the-world, the human being is in a state of Offenheit openness, and often in this state lives in a range of possibilities between healthy living and sickness. Existentially, disease should be regarded as a form of deprivation, but always in the sense of deprivation of capability of being, of being in the world. It brings with it a need in which the individual is understood to be a lack of could-be alternatives, meaning to protrude beyond themselves and rescue the lost freedom in sickness, thus becoming a prisoner of it ${ }^{(13)}$. Given this thinking, it was established in the participants' statements that they were experiencing what once permeated their imaginations, and due to the pain caused by cancer beyond their physical suffering, they felt limited in meeting their own needs, but especially by living as a captive in their own homes.

Currently, the biopsychosocial concept of pain is widely accepted, as the pain may involve a complex combination of physical dysfunctions, beliefs, coping strategies, evolution of the disease and the patient's social interactions. Following this thinking, the treatment of pain often is multidisciplinary relief and seeks to maximize its motility and increase the patient's independence and quality of life ${ }^{(14)}$. However, despite major advances in cancer treatment in recent decades, attention to all the symptoms of this disease being both physical and psychological and the treatment, has lower priority in clinical settings ${ }^{(15)}$.

Having confined pain in living with cancer leads the elderly to suffer a significant reduction in their quality of life, being reflected in their sleep, in carrying out their daily activities, the reduction of their cognitive capacity and predisposing them to great anxiety ${ }^{(16)}$, as it completely restricts their social life. From analyzing the dialogues of the elderly, it was apparent that the consequences of the pain in their daily lives were devastating. The interviews demonstrated how difficult it was to live under its captivity, they felt trapped and unable to cope within their own homes, living with uncertainties about the future, impaired with advancing age and with the limitations imposed by the cancer pain.

Pain is a major concern in cancer patients whether in active treatment or not ${ }^{(14)}$. It is one of the most feared aspects of cancer, and may have an important impact on the lives of human 
beings ${ }^{(17)}$. Reinforcing this fact was a study conducted with six nurses who provided care to patients with cancer and pain in a palliative care unit, which pointed out that the associated pain of falling ill with cancer makes this experience even more complex, since it is a phenomenon which triggers limitation feeling confined to a bed, meaning the loss of freedom to act themselves and in their lives, and on plans made ${ }^{(6)}$.

In this existence, many changes associated with cancer pain deprive the elderly of their health and freedom, and if not detected can lead to complications which makes them prisoners of pain and disease. In the testimonies we observed that the pain affects sleep patterns and appetite/diet, generating discomfort and sadness.

In Heidegger's meditation, the human being is a being in the world that always exists in relation to something or someone, and in this state understands their experiences, establishing their own meaning to objects and beings in their world, and gives meaning to their existence ${ }^{(10)}$. In this light, the pain felt by the elderly also made them close themselves off, preventing them from maintaining relationships with others who went to them to establish bonds of companionship and concern.

It is therefore important to be aware of the risk of depression in cancer patients, which displays as two to three times higher in these patients than in the general population $^{(15)}$. Adding to this, in despite of the existence of several effective approaches to pain management, this symptom is often not adequately treated. When that happens, it may lead to the person experiencing significant distress ${ }^{(17)}$. Individual neurobiological factors may play a role in the relationship between cancer and depression, but much evidence suggests that in this population it represents a final common pathway of suffering resulting from the interaction of various risk factors and vulnerability ${ }^{(15)}$.

One of the most common comorbidities in patients with cancer is depression due to pain and its consequences, and the submission to them, leading to negative impacts on their quality of life and treatment of disease. Its symptoms include mood swings, sleep disturbances, changes in appetite and weight, loss of energy, increased or decreased psychomotor activity, decreased ability to concentrate, feelings of guilt, suicidal thoughts and low self-esteem ${ }^{(5)}$.

Cancer pain should then be seen as a multidimensional occurrence, which makes the experience of distressing sickness and suffering to overcome the physical dimensions and extend to the psychological and social fields ${ }^{(6)}$, referring the patient who is emerged in their own existential prison, to total pain.

In Heidegger's thought, the authentic human existence is characterized by living according to the mode of being, by being aware of their own limitations and taking on the condition of being released into the world, transcending its vicissitude and overcoming existential factuality. Thus, in the statement of Determination there was initially, in experiencing a strong picture of pain, she was entangled in it, seeking an understanding for her situation. However, it was possible to distinguish in a second moment that she seeks the strength within herself to stand firm and support this new and unwanted condition to exist in the world with cancer, living with pain.
Some people diagnosed with cancer express a personal learning that begins in the struggle for survival and they go through the anxiety of living with an uncertain future. This personal learning is experienced through a changed life for themselves when they have to confront the consequences of the disease $\mathrm{e}^{(18)}$.

The pain reflects the uniqueness of the human being, which is an inherent characteristic of this ${ }^{(2)}$. Each elderly was then perceived as the look that they had about their disease and pain, and their way to experience it, reflecting the way we see the world around us, our life-world. In this sense, the pain is something that encourages the elderly to cope with their disease and that in each being there is a unique being, which experiences a unique experience, every human being carries with it a body of knowledge that should always be valued ${ }^{(19)}$, which means that professionals should be aware of the real needs of the elderly who seek the relief of death for their pain.

In Heidegger's thinking, the being-for-death, that is in the possibility of death, being-there authentically exists, that is it finds itself in a condition of being released-from-the-world and the facticity of their existence ${ }^{(10)}$. However, this anticipation of death does not mean the premonition of the time of their arrival, neither a speculation of how will this time be, but sure of its coming in time. However, in the words of the elderly it was noticed that the pain is so unbearable that they feel the need to get away, to leave this existence marked by suffering and at those times, cry to God in anticipating their death, eliminating their agony and consternation.

The feeling of anxiety elevates man to their ontological status; it can be understood as a feeling of redemption. The distressed man is meaningless, for distress is found in a totalizing approach covering all his thinking and acting ${ }^{(20)}$. In this context, in the testimony of Hope it was observed that cancer pain took over her life, leaving her in the dark about her existence. This attitude could be a cry of inauthenticity, of not taking in their possibilities of being-there with pain; it's a way of being that is not based on your original sense of pure possibility.

In face of the above, it is important that nurses give care to sick elderly with cancer, they learn to recognize the pain in all its dimensions, addressing the total pain. They have to deal with it properly as well as distinguish the changes and peculiarities involving the elderly for planning their care actions. Individualized care for the elderly with cancer pain is important, covering the subject of context experienced by $\mathrm{it}^{(6)}$. This is highlighted by the evidence that the attention given to patients with chronic pain eases their anxiety, and consequently relieves their pain and leads to improvement of their depression. Nurses and other health professionals can use the attention to complement the treatment of patients with chronic pain, especially those with psychological comorbidities ${ }^{(21)}$.

However, patients and their families are not getting the information and care necessary for the treatment of cancer. Yet, despite the growing number of new diagnoses of the disease and the number of elderly patients, there is a shortage of skilled labor to take care of this population $^{(22)}$, as many health professionals do not have 
adequate knowledge or preparation to deal with all aspects of the pain, resulting in a change in their quality of life and their ability to cope with the disease $e^{(9,23)}$.

Therefore, the study contributes to the comprehensive and holistic nursing practice to highlight the importance of considering the subjective demands of the elderly affected by cancer pain. It also proves the need for appropriate training of health care professionals who will act in the care of these individuals so that they are able to assess and understand the elderly with cancer pain in all its aspects, to promote their quality of life from qualified and humanized care. However, the study highlights the need for more studies exploring the subject due to the change in demographic and epidemiological profile of the population, it is necessary to contribute to the resolution of new demands.

\section{CONCLUSION}

From the testimonies of the elderly it was possible to understand that pain penetrates their daily lives, making them feel trapped and at the mercy of its consequences and limitations. They found themselves trapped in their own homes and suffered from the charges incurred by it in their lives. It was also observed in the statements that the pain generated restrictions on their activities of daily living, such as diet modifications, sleeping problems and their relationships with the people around them. It also made them live with the uncertainty of what was to come, augmenting the agony of the experience while both fearing and pleading for death.
From these findings, it can be stated that pain originating from cancer for the elderly is referred to as a total pain; it impacts the biopsychosocial framework and generates multidimensional changes.

Dealing with the elderly who are experiencing cancer pain is complex. Some viewed the pain as a symptom that drove them to continue living, seeking a cure for the dreaded disease. However, the impossibility of improvement coupled with the sense of dread made other seniors at certain times wish to not keep on living, leading them to ask for death itself, or even to have suicidal thoughts as a last resort which might relieve their suffering.

This study had some limitations characterized by the specificity of the study population and for taking place in a local reality. However, the experiences of older people with oncological pain reflects the need to carry out actions that support and monitor the elderly who are diagnosed with cancer in their daily lives, to try to support them in their needs for natural and holistic treatment.

Thus, it appears that even with the development of studies regarding the treatment of cancer pain, it is essential to pay special attention to the care of the elderly who experience this situation. Understanding this experience enables the planning and development of humanized actions that address the needs of older people, improving their quality of life and coping with the disease, and so they do not seek measures of suicide as a mechanism of pain relief and receive worthy treatment as they grow older.

\section{RESUMO}

Objetivo: Compreender a vivência com a dor oncológica por idosos. Método: Pesquisa qualitativa alicerçada na fenomenologia heideggeriana. Foram entrevistados 12 idosos em um município do noroeste do Paraná, no período de novembro de 2013 a fevereiro de 2014. Resultados: Da análise realizada por meio da compreensão vaga e mediana e compreensão interpretativa, emergiram duas temáticas ontológicas: A dor oncológica: desvelando o aprisionamento e as imposições vivenciadas pelos idosos e Desvelando a angústia de conviver com a dor oncológica, que revelaram não apenas como os idosos vivenciam a dor em seu cotidiano, mas o quão difícil é conviver com suas peculiaridades. Conclusão: A dor do câncer, para os idosos, tem repercussões biopsicossociais, gerando alterações em seu existir no mundo, exigindo um cuidado holístico e autêntico.

\section{DESCRITORES}

Idoso; Neoplasias; Dor; Enfermagem Oncológica.

\section{RESUMEN}

Objetivo: Comprender la vivencia con dolor oncológico por ancianos. Método: Investigación cualitativa cimentada en la fenomenología heideggeriana. Fueron entrevistados 12 ancianos en un municipio del noroeste de Paraná, en el período de noviembre de 2013 a febrero de 2014. Resultados: Del análisis llevado a cabo por medio de la comprensión vaga y mediana y comprensión interpretativa, surgieron dos temáticas ontológicas: El dolor oncológico: desvelando el aprisionamiento y las imposiciones vividas por los ancianos y Desvelando la angustia de convivir con el dolor oncológico, que revelaron no solo cómo los añosos viven el dolor en su cuotidiano, sino cuán difícil es convivir con sus peculiaridades. Conclusión: El dolor del cáncer, para los ancianos, tiene repercusiones biopsicosociales que causan cambios en su existir en el mundo y requieren un cuidado holístico y auténtico.

\section{DESCRIPTORES}

Anciano; Neoplasias; Dolor; Enfermería Oncológica.

\section{REFERENCES}

1. Jiménez Díaz MC, Pulido Jiménez MC, Villanueva Lupión C, Villar Dávila R, Calero García MJ. El envejecimiento, la asignatura olvidada en la universidad española: ¿El iceberg de un tipo de negligencia? Gerokomos [Internet]. 2011 [citado 2014 ago. 5]; 22(1):8-12. Disponible en: http://scielo.isciii.es/pdf/geroko/v22n1/comunicacion1.pdf

2. Soares LC, Santana MG, Muniz RM. O fenômeno do câncer na vida de idosos. Ciênc Cuid Saúde. 2010;9(4):660-7. 
3. Reyes Chiquete D, González Ortiz JC, Mohar Betancourt A, Meneses García A. Epidemiología del dolor por câncer. Rev Soc Esp Dolor [Internet]. 2011 [citado 2014 ago. 5];18(2):118-134. Disponible en: http://scielo.isciii.es/pdf/dolor/v18n2/revision1.pdf

4. Drageset J, Corbett A, Selbaek G, Husebo BS. Cancer-related pain and symptoms among nursing home residents: a systematic review. J Pain Symptom Manage. 2014;48(4):699-710.

5. Carulla J, Jara C, Sanz J, Martínez C, Ledesma F, Zubillaga E. Dolor como factor predictor de depresión en elpaciente oncológico: estudio de casos y controles. Estudio D-PRESS. Rev Soc Esp Dolor [Internet]. 2013 [citado 2014 ago. 5];20(3):113-21. Disponible en: http://scielo. isciii.es/pdf/dolor/v20n3/03_original.pdf

6. Waterkemper R, Reibnitz KS. Cuidados paliativos: a avaliação da dor na percepção de enfermeiras. Rev Gaúcha Enferm. 2010 ;31(1): 84-91.

7. González-Escalada JR, Camba A, Casas A, Gascón P, Herruzo I, Núñez-Olarte JM, et al. Código de buena práctica para el control del dolor oncológico. Rev Soc Esp Dolor [Internet]. 2011 [citado 2014 ago. 5];18(2):98-117. Disponible en: http://scielo.isciii.es/pdf/dolor/ v18n2/especial.pdf

8. International Association for the Study of Pain. Global year against pain in cancer [Internet]. Seattle: IASP; 2009 [cited 2014 Aug 13]. Available from: http://www.iasp-pain.org/Advocacy/Content.aspx?ItemNumber=1309

9. Silva CCS, Vasconcelos JMB, Nóbrega MML. Dor em pacientes críticos sob a ótica de enfermeiros intensivistas: avaliação e intervenções. Rev RENE. 2011;12(3):540-7.

10. Heidegger M. Ser e tempo. Petrópolis: Vozes; 2012.

11. Sales CA, Silva VA, Pilger C, Marcon SS. Music in human terminality: the family members' conceptions. Rev Esc Enferm USP [Internet]. 2011 [cited 2014 Aug 5];45(1):138-45. Available from: http://www.scielo.br/pdf/reeusp/v45n1/en_19.pdf

12. Paula CC, Souza IEO, Cabral IE, Padoin SMM. Analytical movement - Heideggerian hermeneutics: methodological possibility for nursing research. Acta Paul Enferm [Internet]. 2012 [cited 2014 Aug 5];25(6):984-989. Available from: http://www.scielo.br/pdf/ape/v25n6/ en_v25n6a25.pdf

13. Nogueira RP. Extensão fenomenológica dos conceitos de saúde e enfermidade em Heidegger. Ciênc Saúde Coletiva. 2011;16(1):259-66.

14. Thakur D, Dickerson S, Bhutani MK, Junor R. Impact of prolonged-release oxycodone/naloxoneon outcomes affecting patients' daily functioningin comparison with extended-release tapentadol: a systematic review. Clin Ther. 2015;37(1): 212-24.

15. Rodin G. Effective treatment for depression in patients with câncer. Lancet. 2014;384(9948):1076-8.

16. Mencías Hurtado AB, Rodríguez Hernández JL. Trastornos del sueño en el paciente con dolor crónico. Rev Soc Esp Dolor [Internet]. 2012 [citado 2014 ago. 5];19(6):332-4. Disponible en: http://scielo.isciii.es/pdf/dolor/v19n6/revision4.pdf

17. Goodwin PJ, Bruera E, Stockler M. Pain in patients with cancer. J Clin Oncol. 2014;32(16):1637-9.

18. Karlsson M, Friberg F, Wallengren C, Öhlén J. Meanings of existential uncertainty and certainty for people diagnosed with cancer and receiving palliative treatment: a life-world phenomenological study. BMC Palliat Care [Internet]. 2014 [cited 2014 Aug5];13:28. Available from: http://www.ncbi.nlm.nih.gov/pmc/articles/PMC4059734/

19. Guevara B, Zambrano de Guerrero A, Evies A. Cosmovisión en el cuidar de sí y cuidar del outro. Enferm Global [Internet]. 2011 [citado 2014 nov. 19];10 (21). Disponible en: http://scielo.isciii.es/pdf/eg/v10n21/reflexion2.pdf

20. Costa PE. Inautenticidade e finitude em Heidegger. Saberes [Internet]. 2010 [citado 2014 Ago 5];3(n. esp):151-9. Disponível em: http:// www.periodicos.ufrn.br/saberes/article/view/884/819

21. Song Y, Lu H, Chen H, Geng G, Wang J. Mindfulness intervention in the management of chronic pain and psychological comorbidity: a meta-analysis. Int J Nurs Sci. 2014;1(2):215-23.

22. Nekhlyudov L, Levit L, Hurria A, Ganz PA. Patient-centered, evidence-based, and cost conscious cancer care across the continuum: translating the institute of medicine report into clinical practice. CA Cancer J Clin. 2014;64(6):408-21.

23. Ripamonti $\mathrm{Cl}$, Bossi P, Santini D, Fallon M. Pain related to cancer treatments and diagnostic procedures: a no man's land? Ann Oncol. 2014;25(6):1097-106.

Financial Support: : Conselho Nacional de Desenvolvimento Científico e Tecnológico (National Council for Scientific and Technological Development) - CNPq 